\title{
Challenges Faced by Organisations in Providing Employer - Sponsored Child Care Facilities
}

\author{
A. Martina
}

\begin{abstract}
Women in the workforce is once considered to be a hindrance because of the maternity period and the post partum child care that needed to be given by the mother. However, the recent trends of diversity management and the performance of women in certain jobs have made the contribution of women unavoidable in the workforce. This was aimed to know the opinion of the business people regarding employer sponsored child care facilities. The type of research undertaken is the descriptive study as the study tries to identify the opinion of the management and tries to identify a solution to the problems. The results indicates that Managing Directors felt that women employees' contribution is very essential for the success and growth of the organization.
\end{abstract}

Keywords : Child Care Facilities, HR Managers, Challenges and Problems.

\section{INTRODUCTION}

The entry of women in the workforce is once considered to be a hindrance because of the maternity period and the post partum child care that needed to be given by the mother. However, the recent trends of diversity management and the performance of women in certain jobs have made the contribution of women unavoidable in the workforce (Oekerman, 1997). This also has made the companies to come out with lot of women friendly policies in the workplace. Recent amendments made to Maternity Benefit Act on 2017 has made it mandatory for the organisations employing more than 50 to set up childcare facilities within the premises(S.S. Rana \& Co. Advocates, 2018). In this regard, this paper intends to identify what are the organisations' opinion about the provision of employer sponsored childcare facilities, what are the practical difficulties the organisations are facing and what are the alternative solutions for these.

\section{REVIEW OF LITERATURE}

A study by Zoharah Omar and Aminah Ahmad (Omar \& Ahmad, 2009) on their research on organisations adopting childcare facilities in a manufacturing organisation explored the various forms of childcare facilities that are provided by various organisations. The results of the study revealed that the manufacturing company set up the child care facility in

Revised Manuscript Received on December 05, 2019.

* Correspondence Author

Dr. A. Martina*, Assistant Professor, Tamil Nadu Dr. Ambedkar Law University, Chennai, India. Email: martinamicheal@gmail.com their company to increase productivity, reduce absenteeism by the women employees and to reduce the turnover of the employees. The study also stressed that the culture of the organisation and the HR employees in the organisation also play a vital role in setting up the facility in the organisation.

Another research by S. Suman Babu \& K. Bhavana Raj (Babu \& Raj, 2013) on how the childcare facilities are used as a tool for retaining women employees tried to find out the relation between the two factors. The results of the study revealed that as the child care facility increases, the retention of the women employees also improves.

A research by Horizons Workforce Consulting on the impact of childcare facilities on the employees revealed that $95 \%$ of the respondents felt that this facility helps them to focus on their jobs. $84 \%$ of the respondents told that they joined the organisation because of the childcare facility available at the organisation (Bright Horizons, 2013). 92\% of them felt they would not be considering a job change because of the child care facility provided. $95 \%$ of the respondents felt that it helps them in reducing stress and balancing the work and life.

Another study by Shilpa Gaidhanion how the childcare facility is used as a fringe benefit by the organisationsfocused on the impact of child care facilities on the management and the employees(Gaidhani, 2018). The research is based on secondary data and the research reveals that the childcare facilities provided is instrumental in improving the performance of the employees of the organisation.

\section{RESEARCH GAP}

The review of the literature by the researcher revealed that there are few researches on this potential area of study. There are only two empirical researches conducted on this area one in the manufacturing sector and another in the IT sector. One research is using the secondary data. There are only two researches conducted in India. Hence, the researcher identified this as the potential area of research and had taken up the research in this area.

\section{RESEARCH PROBLEM}

The employer sponsored childcare facilities offer a lot of benefits to the organisations, the women employees and the child itself. The organisations were able to improve their productivity, reduce absenteeism and turnover, can able to get better recruits for the organisation etc. Similarly, the women employees were able to continue their job even after 
child birth, can be relieved from the stress and were able to better manage their work and life.

The kids also can get the immediate attention of their mother, in case of problems they are near to their mother. However, the employer sponsored facilities comes out with their own challenges as well. It increases the financial burden of the employer, employee team work problems and liability issues on the part of the employer in the event of any mis-happenings. The government has also made it mandatory for the organisations to come out \ with crèche facility when the number of women employee is more than 50. It is in this context the researcher had tried to identify what are the possible challenges faced by the employer while giving child care facilities.

\section{OBJECTIVES}

The following objectives has been framed by the researcher

- To know the opinion of the business people regarding employer sponsored child care facilities

- To know the problems faced by the organisations in implementing this facility

- To know the difference of opinion among the HR managers and the Managing Directors on the importance and the challenges faced on implementation

- To offer solutions to overcome the challenges faced

\section{RESEARCH METHODOLOGY}

The type of research undertaken is the descriptive study as the study tries to identify the opinion of the management and tries to identify a solution to the problems. The population for the study will include the decision makers in the organisations who employ women employees. The population for the study is unlimited. Hence, a non probability convenience sampling technique is adopted for the collection of the data. The sample selected is the businessmen and HR managers in the organisations. A sample of 50 is taken for the research work. A structured, close ended questionnaire was framed in order to collect the data from the sample population. The reliability of the measurement tool was tested for the study variables and the results were presented below.

Table -1 : Reliability test

\begin{tabular}{|l|c|c|}
\hline \multicolumn{1}{|c|}{ Study variables } & $\begin{array}{c}\text { No. of } \\
\text {.Items }\end{array}$ & $\begin{array}{c}\text { Alpha } \\
\text { co-efficient }\end{array}$ \\
\hline $\begin{array}{l}\text { Opinion about employer sponsored childcare } \\
\text { facility }\end{array}$ & 6 & 0.817 \\
\hline $\begin{array}{l}\text { Challenges in employer sponsored childcare } \\
\text { facility }\end{array}$ & 6 & 0.924 \\
\hline Overall reliability & 12 & 0.910 \\
\hline
\end{tabular}

Source: Primary data

The Cronbach's Alpha reliability statistics for overall perception about child care facilities found out 0.910 . Inter consistency between the variables are also performed. The result shows that excellent inter-consistency between the study variables. The area of the study includes the business organisations in Tamil Nadu. The questionnaires are distributed to the targeted sample through Google forms and e-mails. Descriptive statistics and ' $t$ ' test were used to analyse the data obtained.

\section{RESULTS AND FINDINGS}

Descriptive analysis

Table - 2: Demographic profile of the respondent

\begin{tabular}{|l|c|c|}
\hline & Number & Percentage \\
\hline Gender & 42 & 84 \\
\hline Male & 8 & 16 \\
\hline Female & 25 & 50 \\
\hline Job profile & 50 \\
\hline Managing director & 25 & \\
\hline HR managers &
\end{tabular}

Most of the respondents are male and only $16 \%$ of the respondents were female. $50 \%$ of the respondents were Managing Directors of the companies and $50 \%$ of the respondents were the HR managers.

Table - 3: Number of women employees working in the organisation

\begin{tabular}{|l|c|c|}
\hline \multicolumn{1}{|c|}{ No. Of women employees } & Number & Percentage \\
\hline $10-20$ & 19 & 38 \\
\hline $21-30$ & 2 & 4 \\
\hline $31-40$ & 8 & 16 \\
\hline $41-50$ & 13 & 26 \\
\hline Above 50 & 8 & 16 \\
\hline Total & 50 & 100 \\
\hline
\end{tabular}

Source: Primary data

Around $38 \%$ of the respondents told there are around 10-20 women employees in their organisation and $26 \%$ of the respondents told that their organisation employs 41-50 women employees. Only $4 \%$ of the respondents told that their organisation engage 21-30 women employees.

Table - 4: Opinion about the importance of women

\begin{tabular}{|c|c|c|}
\hline \multicolumn{3}{|c|}{ employees } \\
\hline Yes & Number & Percentage \\
\hline No & 50 & 100 \\
\hline Total & 0 & 0 \\
\hline
\end{tabular}

Source: Primary data

All the respondents, the Managing directors and HR managers felt that women employees are very important for the success of the organisation.

Table - 5: Reasons for women employees to quit their job

\begin{tabular}{|l|c|c|}
\hline Reasons for attrition of Women employees & Number & Percentage \\
\hline Better job opportunity & 0 & 0 \\
\hline Marriage & 24 & 48 \\
\hline Child care & 22 & 44 \\
\hline \\
$\begin{array}{l}\text { Published By: } \\
\text { Blue Eyes Intelligence Engineering } \\
\text { \& Sciences Publication }\end{array}$
\end{tabular}




\begin{tabular}{|l|c|c|}
\hline Relocating & 4 & 8 \\
\hline Other & 0 & 0 \\
\hline Total & 50 & 100 \\
\hline
\end{tabular}

$48 \%$ of the respondents felt that women quit their job on account of marriage and $44 \%$ of them felt that they quit their job due to child birth.

Table - 6: Opinion on child care facilities will help to retain the women employees

\begin{tabular}{|c|c|c|}
\hline & Number & Percentage \\
\hline Yes & 42 & 84 \\
\hline No & 8 & 16 \\
\hline Total & 50 & 100 \\
\hline
\end{tabular}

Source: Primary datal

Majority of the respondents (84\%) felt that the provision of childcare facility by the employer will help the organisations to retain the women employees:

Table - 7: Opinion about provision of the child care facilities by the organisation

\begin{tabular}{|c|c|c|c|c|c|}
\hline $\begin{array}{l}\text { Opinion of the respondents about the provision of employer sponsored childcare } \\
\text { facilities }\end{array}$ & $\begin{array}{l}\text { Strongly } \\
\text { agree }\end{array}$ & Agree & Neutral & Disagree & $\begin{array}{l}\text { Strongly } \\
\text { disagree }\end{array}$ \\
\hline On reducing the stress level of women employees & 23 & 10 & 12 & 1 & 4 \\
\hline On improving the productivity of the employees & 9 & 29 & 4 & 8 & 0 \\
\hline On getting more talented women employees for the organisation & 18 & 5 & 15 & 8 & 4 \\
\hline On women employees extending extra time & 13 & 15 & 9 & 13 & 0 \\
\hline On reducing absenteeism & 22 & 24 & 0 & 0 & 4 \\
\hline On reducing turnover & 23 & 22 & 0 & 0 & 4 \\
\hline
\end{tabular}

Source: Primary data

$66 \%$ of the respondents agreed that the child care facilities provided by the employer will help the women employees to reduce the stress levels and focus on their job. $74 \%$ of them felt that the employer sponsored childcare facilities will improve the productivity of the employees. Around $46 \%$ of the respondents felt that employer sponsored childcare facilities will get more talented recruits for the organisation. $56 \%$ of the respondents felt that the women employee will stay back to complete their assignments if the child care facility is provided.Around $92 \%$ of the respondents felt that the absenteeism of the women employees will considerably reduce if the organisation is providing the childcare facility within the organisations premises. And a majority of $90 \%$ of the respondents felt that the employees' turnover will reduce if the organisation is providing his facility.

Table - 8: Opinion of the respondents on the possible challenges faced

\begin{tabular}{|c|c|c|c|c|c|c|c|c|c|c|}
\hline \multirow{2}{*}{$\begin{array}{c}\text { Challenges faced on implementing employer sponsored } \\
\text { childcare facilities }\end{array}$} & \multicolumn{2}{|c|}{ Strongly agree } & \multicolumn{2}{|c|}{ Agree } & \multicolumn{2}{|c|}{ Neutral } & \multicolumn{2}{|c|}{ Disagree } & \multicolumn{2}{|c|}{$\begin{array}{l}\text { Strongly } \\
\text { disagree }\end{array}$} \\
\hline & No & $\%$ & No & $\%$ & No & $\%$ & No & $\%$ & No & $\%$ \\
\hline Cost overrun for the organisation & 4 & 8 & 9 & 18 & 12 & 24 & 14 & 28 & 11 & 22 \\
\hline Negative impact on the people who doesn't avail the facility & 5 & 10 & 0 & 0 & 10 & 20 & 36 & 72 & 0 & 0 \\
\hline On spending more time in the childcare centre & 8 & 16 & 23 & 46 & 8 & 16 & 6 & 12 & 5 & 10 \\
\hline $\begin{array}{l}\text { Occurrence of negative incidents affecting the reputation of the } \\
\text { firm }\end{array}$ & 4 & 8 & 9 & 18 & 4 & 8 & 22 & 44 & 11 & 22 \\
\hline Profitability on running a centre for few employees & 9 & 18 & 15 & 30 & 14 & 28 & 4 & 8 & 8 & 16 \\
\hline
\end{tabular}




\begin{tabular}{|l|l|l|l}
\hline 0 & 20 & 40 & 12
\end{tabular}

24

\begin{tabular}{|l|l|l|l|}
\hline 4 & 8 & 4 & 8 \\
\hline
\end{tabular}

Source: Primary data

$50 \%$ of the respondents disagreed that the provision of this facility will lead to the cost overrun in the organisation. Around $92 \%$ of the respondents felt that it will not have negative impact on the people who don't utilise the childcare facility. $62 \%$ of the respondents disagreed to the statement that the women may spend more time in the childcare centre.
Around $66 \%$ of them felt that any unwanted events at the childcare centre will impact the reputation of the firm. $48 \%$ of the respondents felt that it is unprofitable to run a childcare facility for a few employees. Around $60 \%$ of the respondents felt that charging the employees for the childcare facilities offered will reduce the morale of the employees.

\section{A. Hypothesis testing}

\section{t-Test for designation and perception towards the importance and challenges in implementing child care facilities}

Null hypothesis $\left(\mathbf{H}_{\mathbf{0}}\right)$ : There is no significant difference between the designation of the respondents towards the opinion on the importance and challenges in implementing child care facilities

Alternate hypothesis $\left(\mathbf{H}_{\mathbf{a}}\right)$ : There is a significant difference between the designation of the respondents towards the opinion on the importance and challenges in implementing child care facilities

Table - 9: Group Statistics

\begin{tabular}{|c|c|c|c|c|c|}
\hline & Designation & N & Mean & Std. Deviation & Std. Error Mean \\
\hline \multirow{3}{*}{ Opinion } & HR manager & 25 & 2.8733 & 1.18369 & .23674 \\
\cline { 2 - 6 } & Managing Director & 25 & 3.0467 & .12285 & .02457 \\
\hline \multirow{2}{*}{ Challenges } & HR manager & 25 & 3.5467 & 1.25878 & .25176 \\
\cline { 2 - 6 } & Managing Director & 25 & 4.1333 & .40825 & .08165 \\
\hline
\end{tabular}

Table - 10: Independent Samples Test

\begin{tabular}{|c|c|c|c|c|c|c|c|c|c|}
\hline & \multicolumn{2}{|c|}{$\begin{array}{l}\text { Levene's Test for } \\
\text { Equality of Variances }\end{array}$} & \multicolumn{7}{|c|}{ t-test for Equality of Means } \\
\hline & \multirow[t]{2}{*}{$\mathbf{F}$} & \multirow[t]{2}{*}{ Sig. } & \multirow[t]{2}{*}{$\mathbf{t}$} & \multirow{2}{*}{ df } & \multirow{2}{*}{$\begin{array}{c}\text { Sig. } \\
(2 \text {-tailed) }\end{array}$} & \multirow{2}{*}{$\begin{array}{c}\text { Mean } \\
\text { Difference }\end{array}$} & \multirow{2}{*}{$\begin{array}{l}\text { Std. Error } \\
\text { Difference }\end{array}$} & \multicolumn{2}{|c|}{$\begin{array}{l}\text { 95\% Confidence Interval } \\
\text { of the Difference }\end{array}$} \\
\hline & & & & & & & & Lower & Upper \\
\hline $\begin{array}{c}\text { Opinion } \\
\text { Equal variances assumed }\end{array}$ & 32.021 & .000 & -.728 & 48 & .470 & -.17333 & .23801 & -.65188 & .30522 \\
\hline Equal variances not assumed & & & -.728 & 24.517 & .473 & -.17333 & .23801 & -.66401 & .31734 \\
\hline $\begin{array}{l}\text { Challenges } \\
\text { Equal variances assumed }\end{array}$ & 13.699 & .001 & -2.217 & 48 & $.031 *$ & -.58667 & .26467 & -1.11881 & -.05452 \\
\hline Equal variances not assumed & & & -2.217 & 28.994 & $.035^{*}$ & -.58667 & .26467 & -1.12797 & -.04536 \\
\hline
\end{tabular}

*significant at $5 \%$ levelSource: Primary data

The above results indicated that the 'p' values are significant at 5\% level only for the challenges faced by the respondents with regard to child care facilities. From the mean score analysis, it can be understood that compared to HR managers, the managing directors of the companies are giving importance for the implementation of child care facilities. Hence, the null hypothesis is partly rejected and it may be concluded thatthere is a significant difference between the designations of the respondents towards the challenges of child care facilities.

\section{IMPLICATIONS AND CONCLUSION}

The research revealed that the major reason why women employees quit their job is $48 \%$ due to marriage and $44 \%$ due to child birth.And $100 \%$ of the HR managers and the Managing Directors felt that women employees' contribution is very essential for the success and growth of the organisation. $84 \%$ of the respondents were positive that this facility will help to retain the women employees.

When considering the opinion of the respondents for the offering of employer sponsored childcare facilities most of them were positive that this will improve the participation of the women in the organisational activities.Overall,all the respondents were positive towards the provision of employer sponsored child care facilities. However, only $42 \%$ of them felt that it will attract better talents into the organisational workforce and $56 \%$ of the respondents felt that they will stay back to complete important work assignments.

The problems that are faced by the employers in offering the child care facilities arethe occurrence of unforeseen eventsthat will have an impact on the reputation of the firm $(66 \%)$ and $60 \%$ of them felt 
that recovering the cost from employees will reduce their morale. Hence, the major problems that the organisations foresee in offering childcare facilities are unprecedented events and bearing the full cost of the childcare facilities.

The ' $t$ ' test results clearly indicated that the HR mangers and the Managing directors are positive on their opinion in implementing employer sponsored childcare facilities.

However, the Managing directors are little apprehensive about the challenges faced while implementing childcare facilities.

It is in this context, the researcher has come out with the suggestion that rather than recovering the full cost of the facility from the employee, a sharing arrangement can be made with the employee to reduce the financial burden on the part of the organisation. And also since the government is very particular about implementing childcare facilities where more than 50 women employees are employed, the government can extend its support in developing the infrastructure. The government can also make it optional and not compulsory. It can come out with certain tax rebate for the organisations that are providing such a facility.

\section{REFERENCES}

1. Babu, S. S., \& Raj, K. B. (2013). Impact of Childcare Assistance (A Work-Life Balance Practice)on Employee Retention in Indian IT Sector. Global Journal of Management and Business Research Interdisciplinary, 13(6), 9-18.

2. Bright Horizons. (2013). The Lasting Impact of Employer-Sponsored Child Care Centers. Retrieved from http://www.brighthorizons.com/ /media/baaef6571dc04ae4802d735ec39 b6745.pdf

3. Gaidhani, S. (2018). Employer-Sponsored Childcare Program : A New Fringe Benefit. International Journal of Advance Research and Development, 3(3), 78-85.

4. Oekerman, R. (1997). Corporate-sponsored child care: Benefits for children, families, and employers. Early Childhood Education Journal, 25(2), 89-92. https://doi.org/10.1023/A:1025668303209

5. Omar, Z., \& Ahmad, A. (2009). Why organisations adopt family-friendly policy: a case of corporate childcare centre in a manufacturing company. Universiti Tun Abdul Razak E-Journal, 5(1), 1-19.

6. S.S. Rana \& Co. Advocates. (2018). India: Creche Facility Under Maternity Benefit Amendment Act, 2017.

\section{AUTHOR PROFILE}



A. Martina The author has completed her MBA from Alagappa Institute of Management, Karaikudi in Human Resource management and Marketing area. She also has completed her NET with JRF. The author had completed her Doctorate in Human Resource Management area. The author has published more than 10 research papers in various journals. The author has more than 10 years of teaching experience in various Institutions in Mumbai and Chennai. She had been the coordinator of BMS course in Mumbai and had been external examiner for Project viva voce. She had been a Resource person for the Entrepreneurship Development program on 'Personality Development' at Alagppa chettiar Polytechnic, Karaikudi. She also had been a Personality Development trainer in SRM Institute for Training and Development for the students. Currently the author is serving The Tamil Nadu Dr. Ambedkar Law University as Assistant Professor. 